\title{
Guo Zhuang: Re-Created Nature in Microcosm
}

\author{
Peifang Sun \\ School of Civil Engineering and Architecture, Zhejiang University of Science and Technology, Hangzhou, China \\ Email: 870684984@qq.com
}

How to cite this paper: Sun, P. F. (2020). Guo Zhuang: Re-Created Nature in Microcosm. Art and Design Review, 8, 209-214. https://doi.org/10.4236/adr.2020.84016

Received: September 27, 2020

Accepted: November 10, 2020

Published: November 13, 2020

Copyright (c) 2020 by author(s) and Scientific Research Publishing Inc. This work is licensed under the Creative Commons Attribution International License (CC BY 4.0).

http://creativecommons.org/licenses/by/4.0/

\begin{abstract}
Guo Zhuang Villa is a famous residence-villa in Hangzhou City, southern China. It is well known for its unique artistic style and its meticulous construction. The villa has a history of over 100 years, initially serving as the residence of Duanfu Song in 1907 Qing dynasty. In the Minguo period (Republic of China), the villa was sold to Shilin Guo. Since that time, the villa has been called "Guo Zhuang"-meaning the villa of the Guo family. Guo Zhuang not only features the elements typical of southern Chinese gardens, with their elegant re-creations of nature, but also has its own unique character, cleverly blending the garden into nature and incorporating two artificial ponds near the West Lake in Hangzhou. This article is on the basis of reading much historical document and bookmaking, researching the formation, the background and the geography of Guo Zhuang Villa, and mainly carries research on its garden location, layout spatial processing, creating artistic mood, the choice and configuration of landscape plants and so on. These are useful references to modern landscape architecture design and construction.
\end{abstract}

\section{Keywords}

Guo Zhuang, Hangzhou, Architecture, Layout, History

\section{Introduction}

Guo Zhuang is one of the best-preserved and most beautiful private villas within traditional Chinese architecture. It is a classic villa garden located near the west lake by the Yanggong Causeway. Guo Zhuang, also popularly known as "Song Zhuang", was originally laid out in 1907 during the Qing dynasty, by a silk merchant named Duanfu Song. In the Minguo period (Republic of China), Song's family fortunes declined and the villa was sold to a cosmetics store (Fengchun Kong). Subsequently, the villa was transferred to Shilin Guo from Fenyang Town, and thus became also known as Fenyang Villa (Ma, 2018). Although this villa has such a complicated history and features several different names, it is 
popularly known as Guo Zhuang. In 1989, the villa was renovated by the government of Xihu District, but the original plan, traditional buildings and the Chinese characters engraved on the gates and pavilions were all carefully retained. Guo Zhuang was opened to the public in 1991.

Guo Zhuang (Figure 1) is a re-created nature in microcosm: it is an imitation of nature, and fully manifests the beauty of nature in limited space (Pan, 2015); it is also an improvement on nature which should show the painstaking efforts of the garden builder in every corner. It has concentrated man-made structures like rockery (artificial hill), fish ponds and all manner of pavilions together with flowers, trees, breezes and moonlight of nature, and has combined all these into an artistic entity in which man and nature can co-exist harmoniously.

Walking into Guo Zhuang garden, one cannot help but be enchanted by its unique oriental flavor; and walking in an atmosphere of tranquility and peace, one will discover something unlikely to be found in Western architecture-delicate and refined, complex and contained in its quietude (Lou, 2016).

\section{The Overall Layout of Guo Zhuang}

Guo Zhuang covers an area of 9788 square metres, and its gross building area is 1629 square metres (Dong, 2000). The area of its two ponds is very large, totalling almost 3000 square metres in size (Figure 1).

The villa has two gates, namely the west gate (adjoining the Yanggong Causeway) and the north gate (abutting the Lotus Breeze Garden). The west gate is the main entrance, while the north gate serves as an exit. Although the west entrance of Guo Zhuang is not very eye-catching in its own right, once one enters, one is confronted with a most striking view, including an exquisite layout, a well-proportioned landscape and many attractive geese and fish swimming in the ponds.

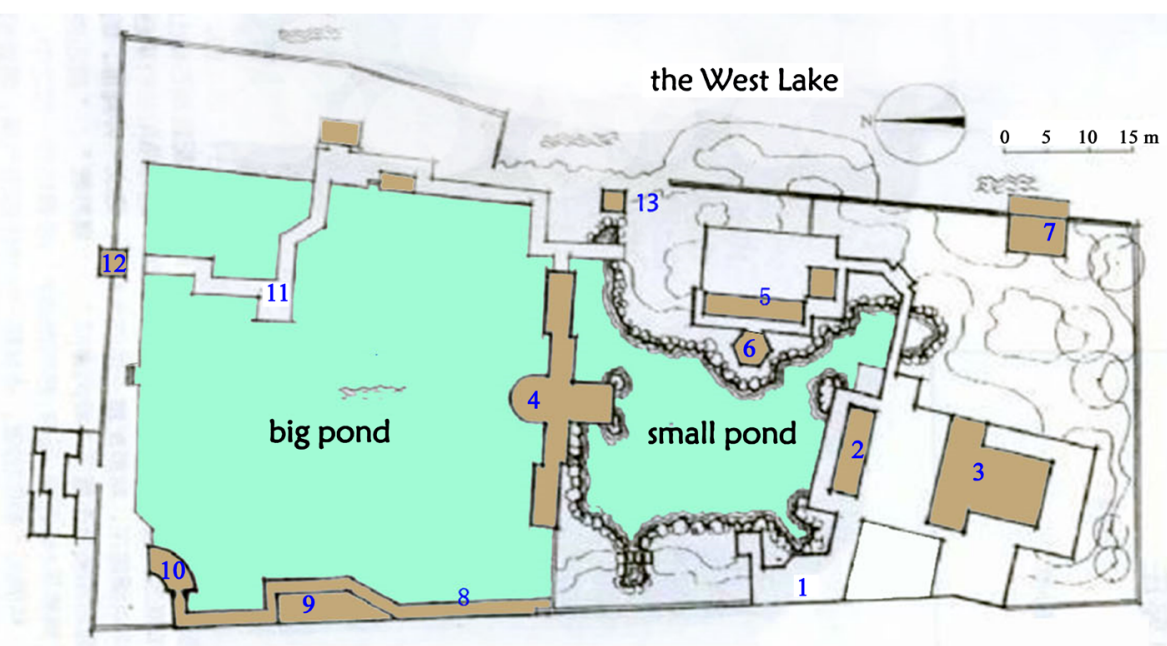

1. the west gate 2. Fragrant Snow Hall 3. West Hill Hall 4.Two-sides Scenery Pavilion

5. Su Causeway Scenery Pavilion 6. algae pavilion 7. moon enjoying pavilion 8.Green Charming Corridor

9. Fragrant Pavilion 10. wind pavilion 11. On Water Bridge 12. the north gate 13. hill pavilion

Figure 1. The layout of Guo Zhuang. 
Overall, the villa comprises two sections: “Quiet Life" (静心居) and the "Mirror Pond" (一镜天开). "Quiet Life" was the area where the owners lived. The chief features of this section are a miscellany of pavilions and structures featuring the unmistakable eaves of the characteristic Chinese architectural roof. A smaller pond was situated here, surrounded by the pavilions, rocks and residential buildings. The "Mirror Pond" section was dominated by water. It featured a larger pond, as clear as a huge mirror, flat and spacious with a slab zigzag bridge and a long roofed-in corridor.

To the east of the villa, a low whitewashed wall separated a slender area abutting the West Lake. The middle section of this wall was broken by an artificial hill. A pavilion, appropriately named Hill Pavilion (赏心悦目亭), was built on the peak of this hill. This slender zone is one of the highlights of the villa design (Tan, 2014). If one stands in this pavilion, it is possible to look over the low wall and enjoy the outside scenery of the Su Causeway and the Northern Hill of the West Lake. This unique and skilful technique was called "scenery-appropriation" by the ancient garden designers: it allowed people to enjoy the view beyond the limited scope of the garden proper.

\section{The Two Sections of Guo Zhuang}

\section{1. "Quiet Life"}

Through the west entrance gate, the visitor arrives first at "Quiet Life". The style of this entrance gate is rather generic in character, just like many other house gates in the city. All the same, it still looks elegant in its brick carving decoration, with traditional architectural details in a style that has endured for almost 100 years. This plain style of Chinese folk art combines elaborate carving with restrained colour.

"Quiet Life" is the residential part of the site. This area is the place in which the majority of the pavilions, the major halls and rooms are located. And it features a small pond and a range of other buildings, such as Fragrant Snow Hall (香雪分春, the main hall of the villa), West HillHall (西山爽气), and Su Causeway Scenery Pavilion (景苏阁). “Quiet Life” is a good place from which to review the traditional aesthetics of Hangzhou.

The central building of this area is Fragrant Snow Hall, which is also the main hall for receiving guests at Guo Zhuang. It was built on a north-south orientation to maximise daylight, with a small courtyard in the back. The main body of the hall is one storey high, and its plan is oblong, thirteen metres in length and eight metres in width. Wood played an important part in the framework and furnishing of this hall. A traditional Chinese wooden framework, "TaiLiang-Shi", (Peng, 2003) was adopted in the construction of the hall. In the "TaiLiang-Shi" framework system, all the beams rest on the tops of pillars, and the load of the roof is carried by the beams and pillars. The roof style of Fragrant Snow Hall is that of the "peaked roof" (a traditional pattern of Chinese gabled roof), in this case including dark grey pantiles. 
On the south side of Fragrant Snow Hall, a courtyard is encircled by several buildings and pavilions. The yard provides a quiet outdoor living space in good weather, and the loosely defined indoor space is well-integrated with it. The pavements of this courtyard are made of robust local grey stone.

To the north of Fragrant Snow Hall is located a small pond. This zone is the focus, and the essence, of Guo Zhuang. The edge of the pond is irregular, with many rocks surrounding it. Several pavilions were built around it (Figure 2). Plants, flowers, grass and trees grow there, in great profusion: the white plum trees are particularly graceful. To the east of the small pond stands an artificial hill piled with an abundance of Taihu stones, to the point where it almost looks like a real mountain. Hill Pavilion (赏心悦目亭), was built on the peak of this hill. Su Causeway Scenery Pavilion is a two-storey high building near the artificial hill, from which one can both overlook the scenery of the villa and enjoy the landscape outside. A stream trickles through a cave in the artificial hill, connecting the ponds to the large West Lake outside.

\section{2. "MirrorPond"}

The "Mirror Pond" area forms the north section of Guo Zhuang. A building named “Twin-sided Scenery Pavilion” (两宜轩) acts as a divider between the Quiet Life and Mirror Pond areas. The "Twin-Sided Scenery Pavilion" rises from the water, and features a wide and open terrace around, from which an excellent view of the goldfish and pink lotus is visible. The pavilion is decorated with exquisite, long windows, through which one can observe the glittering ripples and intriguing inverted images on the water: images of the moon or the clouds,

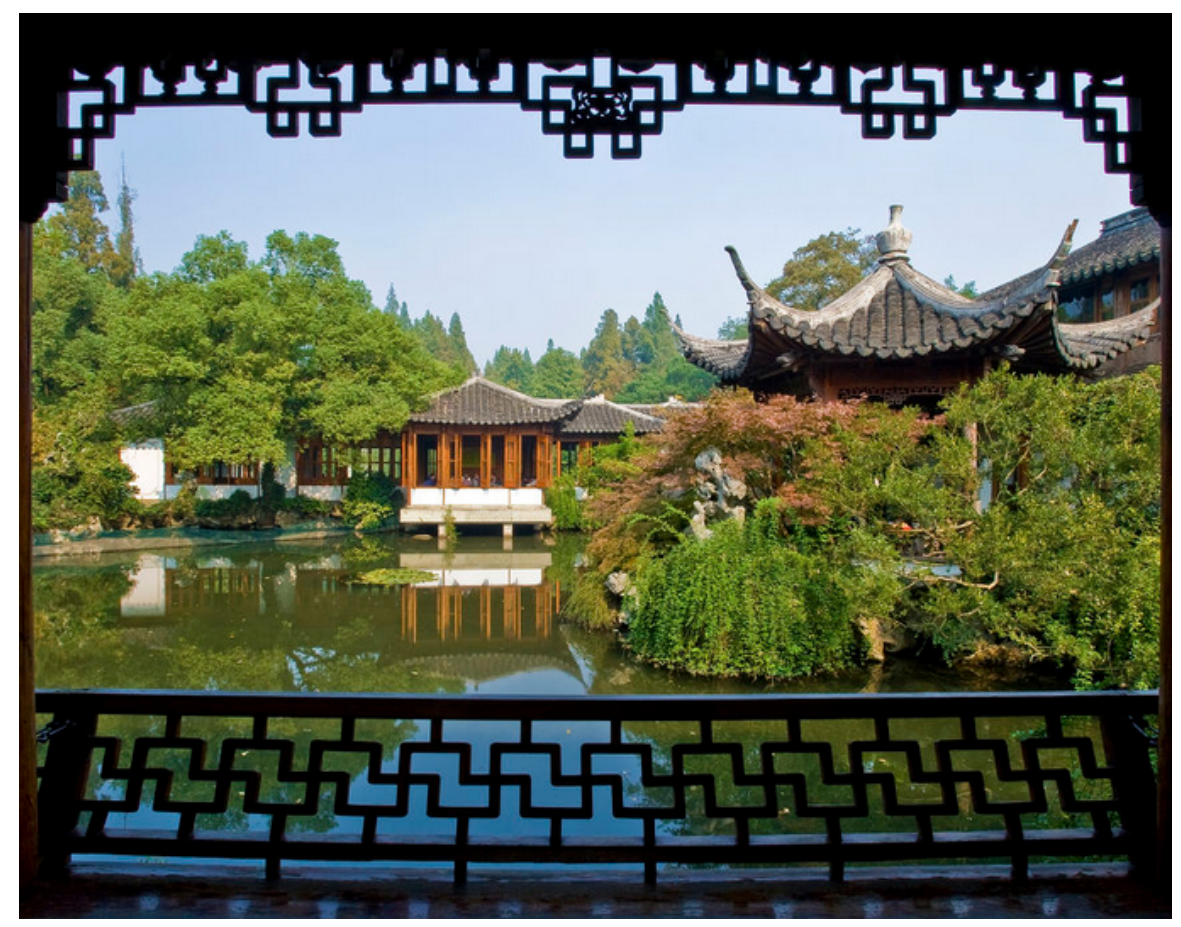

Figure 2. The buildings around the small pond. 
which are all apparently floating on the pond surface. The surrounding water, hills and buildings all can be enjoyed here, just as on a scroll of Chinese paintings.

The "Mirror Pond" is a scenic area of spacious water with complementary architectural scenes. Here the water and the architecture, in combination, form a distinguished, ancient-style garden - an ensemble with infinite fascination. At the north-east of the pond, there is a flat bridge across the water, named "Water Bridge" (卧波桥). The bridge adds strong visual interest to a restricted water area. On the west side, a long, black-eaved corridor runs between the whitewashed garden wall and the large pond. Although limited in size, this pond-garden is nevertheless full of visual interest, and seems very far from cramped, with its winding banks and multiple levels of water.

A rich diversity of vegetation was planted inside the villa, forming a great variety of scenic spots where plants and flowers provide a theme and visual focus. In early spring, plum flowers at the Fragrant Snow Hall (香雪分春) blossom against the cold, and willows at the Green Corridor (翠迷廊) weave a brocade of green colour. In summer-time at the Twin-sided Scenery Pavilion (两宜轩), many lotus flowers blossom on the water surface. In autumn, the fragrance of sweet osmanthus flowers is wafted inside the Fragrant Pavilion(凝香亭); and in winter-time, pines and bamboos in the villa retain their green despite the cold weather (She, 2006).

Pavilions with upturned eaves, stones and artificial hills with rugged edges, exquisite windows on the walls, bushes interspersed with rockery, and ancient plums in front of the pavilion-all these together form a kind of landscape painting around the pond, seen against the southern background of residential walls. All these elements work together so successfully that no sense of monotony or disproportion is found, in relation to the small bridge and pavilion hovering over the water (Cheng, 1999).

\section{Conclusion}

Guo Zhuang not only features the elements typical of southern Chinese gardens, with their elegant re-creations of nature, but also has its own unique character, cleverly blending the garden into nature and incorporating two artificial ponds near the West Lake in Hangzhou.

There are two notable things, above all, about the layout of Guo Zhang. First of all, the villa's key spirit revolves around water, which is clearly highlighted in the layout of the villa. Second, the villa is designed with the elements of yin and yang prominently incorporated into it. This can be seen in the clever way that the garden juxtaposes shade and light, curved and straight. The Guo Zhang Villa can therefore be considered as an ideal embodiment of Chinese Taoism.

It is not only specimen of gardens of China, but also the world's precious cultural heritage. Take a casual stroll in Guo Zhuang, and from the bridges, creeks and ancient pavilions, you can catch a glimpse of the face of Chinese garden 
history (Zhou, 2015).

In the book of Jiangnan Garden Records (江南园林志), Guo Zhuang Villa was highly commended, and hailed as equivalent in standing to the Master of Nets Garden in Suzhou. It was argued to be the most classical of the gardens of Hangzhou. Summing up its significance, the renowned scientist and professor, Chen Congzhou, commented that it embodied a "graceful reproduction, just like a Chinese traditional painting."

\section{Conflicts of Interest}

The author declares no conflicts of interest regarding the publication of this paper.

\section{References}

Cheng, L. R. (1999). Chinese Classical Gardens. Kunming: Yunnan People's Press.

Dong, W. (2000). Old City Renewal and Cultural Heritage Conservation. Architects. Beijing: China Architecture \& Building Press.

Lou, Q. G. (2016). Chinese Gardens (p. 30). Beijing: China Intercontinental Press.

Ma, S. Y. (2018). Ancient Architecture in Hangzhou. Hangzhou: Hangzhou Press.

Pan, G. X. (2015). Chinese Architecture History. Beijing: China Architecture \& Building Press.

Peng, Y. G. (2003). Analysis of Chinese Classical Gardens. Beijing: China Architecture \& Building Press.

She, Z. C. (2006). Details on Chinese Garden. Beijing: Guangming Daily Press.

Tan, L. (2014). Pavilions. Jinan: Shandong Pictorial Press.

Zhou, W. Q. (2015). The History of Chinese Classical Gardens. Beijing: Tsinghua University Press. 